\section{Kidney Blood Pressure Research}

\title{
Uremic Pruritus is Associated with Two- Year Cardiovascular Mortality in Long Term Hemodialysis Patients
}

\author{
Cheng-Hao Weng ${ }^{a, b}$ Ching-Chih Hu ${ }^{b, c}$ Tzung-Hai Yen ${ }^{a, b} \quad$ Ching-Wei Hsu ${ }^{a, b}$ \\ Wen-Hung Huanga,b
}

aDepartment of Nephrology and Division of Clinical Poison Center, Chang Gung Memorial Hospital, Linkou Medical Center, Taoyuan, 'bhang Gung University College of Medicine, Taoyuan, 'Department of Hepatogastroenterology and Liver Research Unit, Chang Gung Memorial Hospital, Keelung, Taiwan

\section{Key Words}

Uremic pruritus $•$ Cardiovascular $・$ Mortality $\bullet$ Hemodialysis

\begin{abstract}
Background/Aims: Uremic pruritus (UP) is an unpleasant complication in patients undergoing maintenance dialysis. Cardiovascular and infection related deaths are the major causes of mortality in patients undergoing dialysis. Studies on the correlation between cardiovascular or infection related mortality and UP are limited. Methods: We analyze 866 maintenance hemodialysis (MHD) patients in our hemodialysis centers. Clinical parameters and 24-month cardiovascular and infection-related mortality are recorded. Results: The associations between all-cause, cardiovascular and infection related mortality with clinical data including UP are analyzed. Multivariate Cox regression demonstrated that UP is a significantly predictor for 24-month cardiovascular mortality in the MHD patients (Hazard ratio: 3.164; 95\% confidence interval, 1.743-5.744; $p<0.001$ ). Conclusion: Uremic pruritus is one of the predictor of 24-month cardiovascular mortality in MHD patients.

\section{Introduction}

Uremic pruritus (UP) is an unpleasant complication in patients undergoing maintenance dialysis (MHD) and the pathogenesis and etiology of UP are not well known and multifactorial [1-4]. The prevalence of UP is in a wide range (22\% to 90\%) [5-7]. It affects not only the patients' quality of life but also death [8-10]. Cardiovascular and infection related death are the major causes of mortality in patients undergoing dialysis [11]. Uremic pruritus has been noted to be a presentation of systemic inflammation [12]. Systemic inflammation is one of
\end{abstract}




\section{Kidney Blood Pressure Research}

the etiologies of cardiovascular mortality in hemodialysis (HD) patients [13]. However, study on the correlation between pruritus and mortality of HD patients is limited. Study on the correlation between cardiovascular or infection related mortality and UP is also limited. Narita showed that severe renal itch is associated with 24-months all cause mortality [10]. Cardiovascular or infection related mortality is not mentioned in the study. The aim of this study is focused on the role of UP on cardiovascular and infection related mortality in patients undergoing MHD.

\section{Materials and Methods}

\section{Patients}

This is a retrospective study. The study patients were recruited from the $3 \mathrm{HD}$ centers of Chang Gung Memorial Hospital, Lin-Kou Medical Center at both the Taipei and Taoyuan branches. Only MHD patients who were 18 years of age or older and had undergone HD for at least 6 months were enrolled in this study. Patients with malignancies or obvious infectious diseases, as well as those who had been hospitalized or had undergone surgery within 3 months of the investigation, were excluded. A total of $1216 \mathrm{HD}$ patients were screened. Eight hundred and sixty six HD patients participated in this study. Most patients underwent 4 hours of HD, 3 times a week, which was performed using single-use hollow-fiber dialyzers equipped with modified cellulose, polyamide, or polysulfone membranes. The dialysate used in all cases had a standard ionic composition with a bicarbonate-based buffer. The cardiovascular diseases (CVDs) were defined as cerebrovascular disease, coronary artery disease, congestive heart failure, and peripheral vascular disease in these patients identified by chart reviews. Infection related mortality was defined as death that was attributed to an acute infectious disease. Infectious disease is defined as an illness caused by a specific infectious organism diagnosed by attending physicians based on various examinations for infectious organisms and clinical suspicions. Hypertension was defined as the regular use of antihypertensive drugs to control blood pressure or at least 2 blood pressure measurements of more than 140/90 $\mathrm{mmHg}$ measured after HD. Senior dermatologists diagnosed the presence of UP. The severity of pruritus was measured by visual analogue scale (VAS), which consisted of a $10-\mathrm{cm}$ horizontal line with 0 point (no pruritus) to 10 points (maximum intensity of pruritus) and was given to patients after HD.

\section{Laboratory, Nutritional, and Inflammatory Parameters}

All blood samples were drawn from the arterial end of the vascular access immediately after the initial 2-day interval for $\mathrm{HD}$ and were then centrifuged and stored at $-80^{\circ} \mathrm{C}$ until use. Serum creatinine $(\mathrm{Cr})$ levels, normalized protein catabolism rate (nPCR), and serum albumin levels were assayed and recorded as nutritional markers. High-sensitivity C-reactive protein (hsCRP) levels were measured as indices of inflammation. All other biochemical indices were measured using a standard laboratory approach with an automatic analyzer. In the HD patients, dialyzer clearance of urea was measured using a method described by Daugirdas and was expressed as Kt/V $\mathrm{V}_{\text {urea }}$. The nPCR of the HD patients was calculated using validated equations and was normalized to the patients' body weight. Anuria was defined as a daily urine amount less than $100 \mathrm{~mL}$ measured by 24 hours urine and in recent 3 months at the time of chart review. Non-anuria was defined as a daily urine amount of $\geq 100 \mathrm{~mL}$. The serum calcium level was adjusted using the serum albumin level with the following formula: corrected calcium level $(\mathrm{mg} / \mathrm{dL})=$ serum calcium level $+0.8 \times(4.0$ - serum albumin level). Twenty-four month cardiovascular and infection-related mortality were recorded.

\section{Statistical Analysis}

The Kolmogorov-Smirnov test was used to test if variables were normally distributed. A P value of $>0.05$ was required to assume a normal distribution. Continuous variables are expressed as the mean \pm standard deviation/median (interquartile range), and categorical variables are expressed as numbers or percentages. Chi- -square or Fisher's exact test was used to analyze the correlation between categorical variables. Comparisons between 2 groups were performed using the Mann-Whitney U test or Student's t-test. Data involving hsCRP, intact parathyroid hormone (iPTH), and ferritin levels were log-transformed for analysis. Univariate and multivariate Cox regression analyses were performed to evaluate the variables 


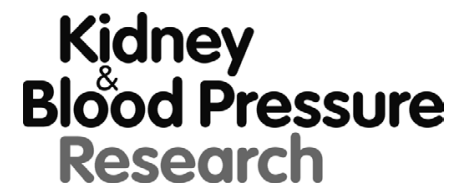

\begin{tabular}{l|l}
\hline Kidney Blood Press Res 2018;43:1000-1009 \\
\hline \begin{tabular}{l|l} 
DOI: 10.1159/000490689 & (c) 2018 The Author(s). Published by S. Karger AG, Basel \\
Published online: 18 June, 2018 & ww.karger.com/kbr
\end{tabular} \\
\hline
\end{tabular}

Weng et al.: Uremic Pruritus and Cardiovascular Mortality

related to UP. Missing data were handled using list-wise deletion. Data were analyzed using SPSS, version 12.0 for Windows 95 (SPSS Inc., Chicago, IL, USA). The level of significance was set at a $\mathrm{P}<0.05$.

\section{Results}

In this 866 MHD patients-included observational study, 189 had UP (21.8\%). The mean age was 56.18 year-old and the mean HD duration was 6.96 years. Between patients with and without UP, significant differences were seen in age (57.93 \pm 12.437 vs $55.70 \pm 13.867$ years, $\mathrm{P}=0.046), \mathrm{DM}(13.2 \%$ vs $24.7 \%, \mathrm{P}=0.001)$, hepatitis $\mathrm{C}$ virus infection (HCV) ( $24.9 \%$ vs $17.9 \%, \mathrm{P}=0.037)$, HD duration $(9.41 \pm 5.43$ vs $6.27 \pm 5.13$ years, $\mathrm{P}<0.001$ ), use of hemodiafiltration (HDF) $(27.5 \%$ vs $19.9 \%, \mathrm{P}=0.028), \mathrm{Kt} / \mathrm{V}_{\text {urea }}(1.89 \pm 0.34$ vs $1.77 \pm 0.32$, $\mathrm{P}<0.001), \mathrm{nPCR}(1.22 \pm 0.27$ vs $1.17 \pm 0.26 \mathrm{~g} / \mathrm{kg} /$ day, $\mathrm{P}=0.003)$, non-anuria condition (11.6\% vs $23 \%, \mathrm{P}<0.001)$, i-PTH levels $[187.2(63.8,401.7)$ vs $121.3(47.7,284.1) \mathrm{pg} / \mathrm{ml}, \mathrm{P}$ $=0.003]$, total cholesterol levels $(176.93 \pm 39.240$ vs $169.73 \pm 37.089 \mathrm{mg} / \mathrm{dl}, \mathrm{P}=0.02), \mathrm{LDL}$ levels $(100.36 \pm 31.058$ vs $93.26 \pm 30.306 \mathrm{mg} / \mathrm{dl}, \mathrm{P}=0.005)$ and cardiovascular death $(6.3 \%$ vs $5.6 \%, \mathrm{P}=0.008$ ) respectively (Table 1 ). Patients with UP had significantly higher allcause mortality in the 24-month period by Kaplan-Meier analysis (Fig. 1, log rank test, $\mathrm{r}^{2}=$ 4.698, $\mathrm{p}=0.03$ ). Patients with UP also had significantly higher cardiovascular mortality in the 24-month period (Fig. 2, log rank test, $r^{2}=7.987, p=0.005$ ). However, patients with UP did not have significantly higher proportion of infection related mortality in the 24-month period (Fig. 3; log rank test, $r^{2}=0.244, p=0.622$ ).

In order to further investigate the significance of UP as an independent predictor for 24-month cardiovascular mortality, the univariate and multivariate Cox proportional hazard regression analysis was used. Univariate Cox regression showed age [odds ratio (OR): 1.066, 95\% confidence interval (CI): 1.042 - 1.090, P < 0.001], DM (OR: 3.153, 95\% CI: 1.816 - 5.475, $\mathrm{P}<0.001$ ), previous CVD history (OR: 3.339, 95\% CI: $1.504-7.413, \mathrm{P}=0.003$ ), log hsCRP (OR: $2.741,95 \%$ CI: $1.593-4.718$, P < 0.001), UP (OR: 2.217, 95\% CI: $1.257-3.911, \mathrm{P}=$ 0.006 ) and cardiomegaly (OR: $1.763,95 \% \mathrm{CI}: 1.013-3.069, \mathrm{P}=0.045$ ) were associated with increased risk of 24-months cardiovascular mortality. On the other hand, fistula as blood access (OR: 0.344, 95\% CI: $0.197-0.601$, P < 0.001), nPCR (OR: 0.231, 95\% CI: $0.076-0.703$, $\mathrm{P}=0.01$ ), hemoglobin level (OR: $0.751,95 \% \mathrm{CI}$ : $0.611-0.923, \mathrm{P}=0.006$ ), serum albumin level (OR: 0.233, 95\% CI: 0.112 - 0.483, P < 0.001) and serum Cr level (OR: 0.736, 95\% CI: $0.649-0.834, \mathrm{P}<0.001$ ) were associated with reduced risk of 24 -months cardiovascular mortality. VAS was not a significant factor to predict 24-month all-cause mortality (HR = $0.89, \mathrm{p}=0.326)$, cardiovascular-related $(\mathrm{HR}=0.85, \mathrm{p}=0.253)$ mortality and infection-related $(\mathrm{HR}=0.97, \mathrm{p}=0.89)$ mortality (Table 2$)$. Despite UP patients having longer HD duration, HD duration was not a predictor of 24-months cardiovascular mortality by univariate Cox regression (OR: 0.97, 95\% CI: $0.91-1.02, \mathrm{P}=0.289$ ). An advanced multivariate Cox regression indicated that after adjusted above mentioned significant variables, age (OR: 1.053, 95\% CI: 1.026 - 1.080, P < 0.001), DM (OR: 2.957, 95\% CI: 1.664 - 5.256, P < 0.001), previous CVD history (OR: 2.845, 95\% CI: $1.267-6.386, \mathrm{P}=0.011$ ), log hsCRP (OR: 2.241, 95\% CI: 1.269 - 3.958, P = 0.005), UP (OR: 2.217, 95\% CI: $1.257-3.911, \mathrm{P}=0.006$ ), fistula as blood access (OR: 0.538, 95\% CI: $0.298-0.972$, P = 0.040), and uremic pruritus (OR: 3.164; 95\% CI: 1.743 $-5.744, \mathrm{P}<0.001$ ) were significant predictors for 24 -month cardiovascular mortality in the MHD patients (Table 3).

Univariate logistic regression showed that body mass index (OR: 1.07, 95\% CI: 1.01 - 1.15, P = 0.036), DM (OR: 0.46, 95\% CI: $0.29-0.73, \mathrm{P}=0.001$ ), HCV (OR: 1.52, 95\% CI: $1.03-2.23, \mathrm{P}=0.032$ ), hemodialysis duration (OR: 1.11, 95\% CI: $1.05-1.15, \mathrm{P}<0.001$ ), hemodiafiltration (OR: 1.52, 95\% CI: $1.05-2.20, \mathrm{P}=0.026), \mathrm{Kt} / \mathrm{V}_{\text {urea }}$ (Daugirdas) (OR: 2.94, 95\% CI: $1.8-4.79$, P < 0.001), nPCR (OR: 1.93, 95\% CI: $1.06-3.51, \mathrm{P}=0.03$ ), non-anuria (OR: $0.44,95 \%$ CI: $0.27-0.71, \mathrm{P}=0.001$ ), serum albumin (OR: 0.57, 95\% CI: $0.36-0.91, \mathrm{P}=$ 0.02), log iPTH (OR: 1.52, 95\% CI: 1.14 - 2.02, P = 0.004), and LDL (OR: 1.01, 95\% CI: 1.00 - 


\section{Kidney Bloód Pressure Research}

$1.01, P=0.005)$ were significant predictors for UP in the MHD patients. Multivariate logistic regression indicated that after adjusted for significant variables analysed by univariate logistic regression, hemodialysis duration (OR: 1.102, 95\% CI: $1.069-1.137, \mathrm{P}<0.001$ ), and LDL (OR: 1.008, 95\% CI: $1.002-1.013, \mathrm{P}=0.006$ ) were significant predictors for UP in the MHD patients (Table 4).

Table 1. Characteristics of studied MHD patients and patients with and without uremic pruritus. Abbreviations: SD: standard deviation; CVD: cardiovascular disease; HBV: hepatitis B virus infection; HCV: hepatitis C virus infection; nPCR: normalized protein catabolic rate; hsCRP: high-sensitivity C-reactive protein; LDL: low density lipoprotein; Kt/ $\mathrm{V}_{\text {urea }}$ : dialysis clearance of urea. *Non-normal distribution data are presented as median (interquartile range)

\begin{tabular}{|c|c|c|c|c|}
\hline Characteristics & $\begin{array}{c}\text { Total (866) } \\
\text { Mean } \pm \\
\text { SD/Median(Range) } \\
\end{array}$ & $\begin{array}{c}\text { Without pruritus (677) } \\
\text { Mean } \pm \\
\text { SD/Median(Range) }\end{array}$ & $\begin{array}{l}\text { With pruritus (189) } \\
\text { Mean } \pm \\
\text { SD/Median(Range) }\end{array}$ & $\mathrm{P}$ \\
\hline \multicolumn{5}{|l|}{ Demographics } \\
\hline Age (years) & $56.18 \pm 13.59$ & $55.70 \pm 13.867$ & $57.93 \pm 12.437$ & 0.046 \\
\hline Male sex, n (\%) & $440(50.8 \%)$ & $352(52 \%)$ & $88(46.6 \%)$ & 0.18 \\
\hline Body mass index $\left(\mathrm{kg} / \mathrm{m}^{2}\right)$ & $22.19 \pm 3.18$ & $22.231 \pm 3.1331$ & $22.063 \pm 3.3742$ & 0.52 \\
\hline Smoking, n (\%) & $150(17.3 \%)$ & $120(17.7 \%)$ & $30(15.9 \%)$ & 0.58 \\
\hline \multicolumn{5}{|l|}{ Dialysis Related Data } \\
\hline Haemodialysis duration (years) & $6.96 \pm 5.35$ & $6.27 \pm 5.13$ & $9.41 \pm 5.43$ & $<0.001$ \\
\hline Erythropoietin (U/kg/week) & $73.62 \pm 47.37$ & $75.0643 \pm 47.71407$ & $68.4568 \pm 45.87704$ & 0.09 \\
\hline Fistula as blood access, $\mathrm{n}(\%)$ & $689(79.6 \%)$ & $532(78.6 \%)$ & $157(83.1 \%)$ & 0.18 \\
\hline Hemodiafiltration, n (\%) & $187(21.6 \%)$ & $135(19.9 \%)$ & $52(27.5 \%)$ & 0.028 \\
\hline $\mathrm{Kt} / \mathrm{V}_{\text {urea }}$ Daugirdes & $1.79 \pm 0.32$ & $1.77 \pm 0.32$ & $1.89 \pm 0.34$ & $<0.001$ \\
\hline nPCR (g/kg/day) & $1.18 \pm 0.26$ & $1.17 \pm 0.26$ & $1.22 \pm 0.27$ & 0.03 \\
\hline $\begin{array}{l}\text { Residual daily urine of }>100 \mathrm{ml}, \mathrm{n} \\
(\%)\end{array}$ & $178(20.6 \%)$ & $156(23 \%)$ & $22(11.6 \%)$ & $<0.001$ \\
\hline Medications for itching, n (\%) & & $33(4.9 \%)$ & $189(100 \%)$ & $<0.001$ \\
\hline \multicolumn{5}{|l|}{ Biochemical Data } \\
\hline Hemoglobin $(\mathrm{g} / \mathrm{dl})$ & $10.51 \pm 1.36$ & $10.482 \pm 1.3431$ & $10.625 \pm 1.4527$ & 0.2 \\
\hline Albumin $(\mathrm{g} / \mathrm{dl})$ & $4.06 \pm 0.34$ & $4.078 \pm 0.3482$ & $4.012 \pm 0.3367$ & 0.019 \\
\hline Creatinine $(\mathrm{mg} / \mathrm{dl})$ & $10.88 \pm 2.39$ & $10.900 \pm 2.4179$ & $10.837 \pm 2.2953$ & 0.74 \\
\hline Ferritin $(\mu \mathrm{g} / \mathrm{l})^{*}$ & $305.0(129.57,504.45)$ & $296(116.6,505.4)$ & $335.2(189.2,499.4)$ & 0.13 \\
\hline Corrected-calcium (mg/dl) & $9.94 \pm 0.93$ & $9.912 \pm 0.9188$ & $10.059 \pm 0.9779$ & 0.055 \\
\hline Phosphate $(\mathrm{mg} / \mathrm{dl})$ & $4.84 \pm 1.35$ & $4.844 \pm 1.3395$ & $4.843 \pm 1.4128$ & 0.99 \\
\hline Intact parathyroid hormone $(\mathrm{pg} / \mathrm{ml})^{*}$ & $130.1(52.52,319.2)$ & $121.3(47.7,284.1)$ & $187.2(63.8,401.7)$ & 0.003 \\
\hline $\mathrm{hsCRP}(\mathrm{mg} / \mathrm{l})^{*}$ & $2.95(1.4,7.01)$ & $2.89(1.38,7.39)$ & $3.04(1.43,5.94)$ & 0.87 \\
\hline \multicolumn{5}{|l|}{ Co-Morbidity } \\
\hline Diabetes mellitus, n (\%) & $192(22.2 \%)$ & $167(24.7 \%)$ & $25(13.2 \%)$ & 0.001 \\
\hline Hypertension, n (\%) & $339(39.1 \%)$ & $266(39.3 \%)$ & $73(38.6 \%)$ & 0.93 \\
\hline Previous CVD, n (\%) & $41(4.7 \%)$ & $34(5 \%)$ & $7(3.7 \%)$ & 0.56 \\
\hline HBV, n (\%) & $98(11.3 \%)$ & $84(12.4 \%)$ & $14(7.4 \%)$ & 0.06 \\
\hline HCV, n (\%) & $168(19.4 \%)$ & $121(17.9 \%)$ & $47(24.9 \%)$ & 0.037 \\
\hline \multicolumn{5}{|l|}{ Cardiovascular Risks } \\
\hline Cholesterol (mg/dl) & $171.3 \pm 37.66$ & $169.73 \pm 37.089$ & $176.93 \pm 39.240$ & 0.02 \\
\hline Triglyceride (mg/dl) & $164.33 \pm 115.8$ & $167.11 \pm 118.676$ & $154.36 \pm 104.573$ & 0.18 \\
\hline $\mathrm{LDL}(\mathrm{mg} / \mathrm{dl})$ & $94.83 \pm 30.59$ & $93.26 \pm 30.306$ & $100.36 \pm 31.058$ & 0.005 \\
\hline Cardiomegaly, n (\%) & $383(44.2 \%)$ & $310(45.8 \%)$ & $73(38.6 \%)$ & 0.083 \\
\hline 24-month Mortality & & & & 0.043 \\
\hline Cardiovascular-related, n (\%) & $50(5.8 \%)$ & $38(5.6 \%)$ & $12(6.3 \%)$ & 0.008 \\
\hline Infection-related, n (\%) & $50(5.8 \%)$ & $31(4.6 \%)$ & $19(10.1 \%)$ & 0.59 \\
\hline Cancer or others related, $\mathrm{n}(\%)$ & $4(0.4 \%)$ & $4(0.6 \%)$ & 0 & 0.58 \\
\hline
\end{tabular}




\section{Kidney Blood Pressure Research}

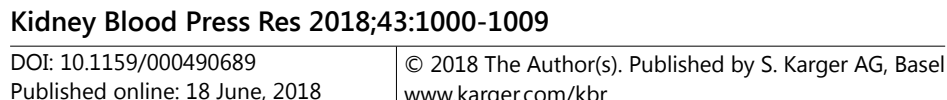

Published online: 18 June, 2018 www.karger.com/kb

Weng et al.: Uremic Pruritus and Cardiovascular Mortality

Fig. 1. Comparison of the 24-month all-cause mortality between patients with and without uremic pruritus by Kaplan-Meier analysis. (Green line: patients with uremic pruritus, blue line: patients without pruritus).

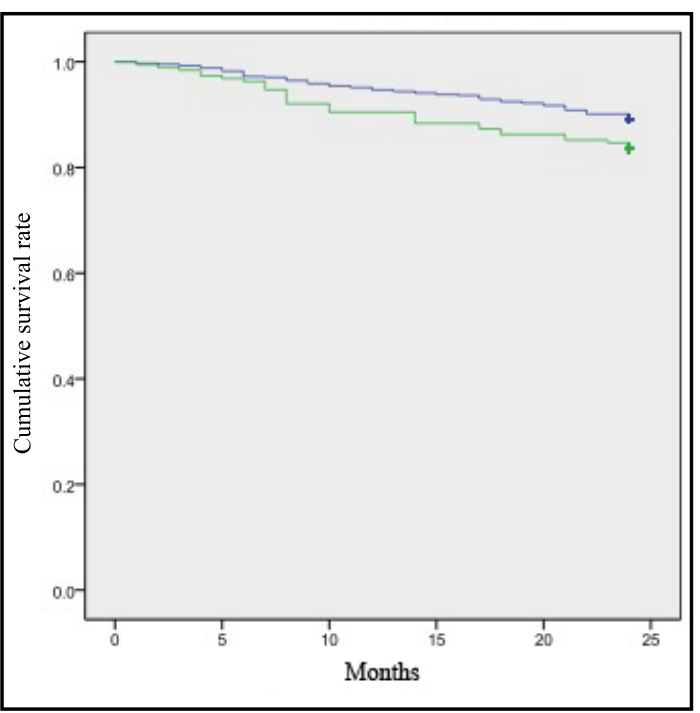

Fig. 2. Comparison of the 24-month cardiovascular mortality between patients with and without uremic pruritus by Kaplan-Meier analysis. (Green line: patients with uremic pruritus, blue line: patients without pruritus).

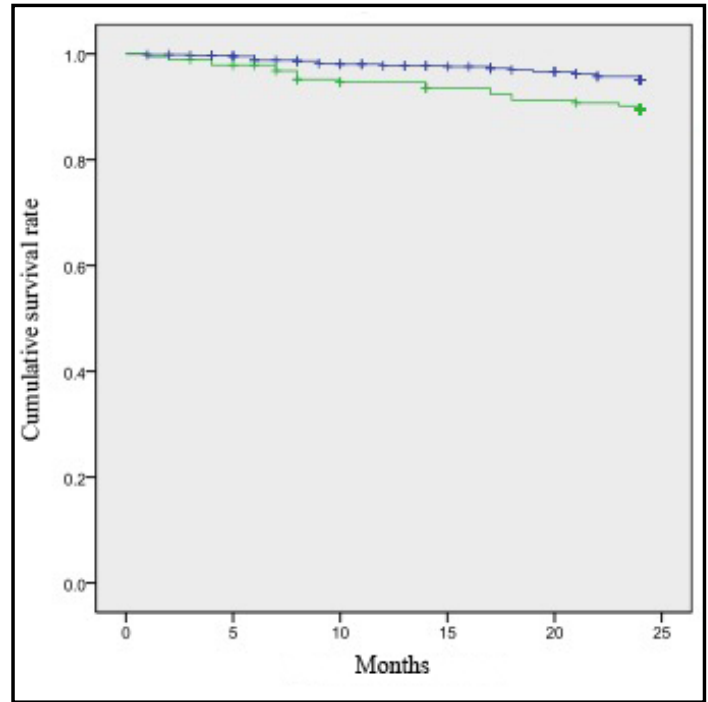

Fig. 3. Comparison of the 24-month infection-related mortality between patients with and without uremic pruritus by Kaplan-Meier analysis. (Green line: patients with uremic pruritus, blue line: patients without pruritus).

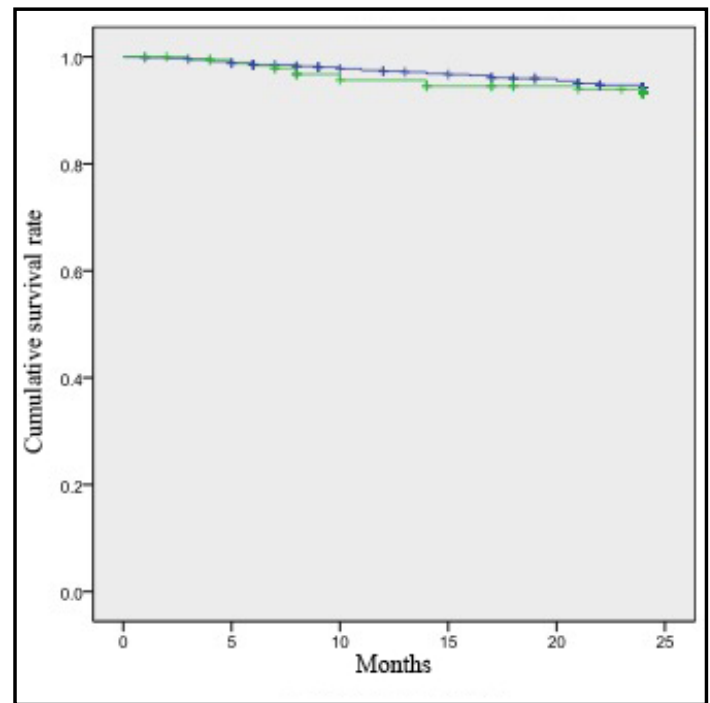




\section{Kidney Blood Pressure Research}

Table 2. Univariate Cox Regression Analysis of 24- month cardiovascular related mortality. Abbreviations: CVD: cardiovascular disease; nPCR: normalized protein catabolic rate; WBC: white blood cell count; HBV: hepatitis B virus infection; HCV: hepatitis C virus infection; hsCRP: high-sensitivity C-reactive protein; iPTH: intact parathyroidhormone; Kt/V urea: dialysis clearance of urea; C-Ca: corrected calcium; LDL: low density lipoprotein; VAS: visual analogue scale

\begin{tabular}{|c|c|c|}
\hline Variables & $\begin{array}{c}\text { Odds ratio (OR) } \\
95 \% \text { confidence Intervals (CI) }\end{array}$ & $\mathrm{p}$ \\
\hline Age (years) & $1.066(1.042,1.090)$ & $<0.001$ \\
\hline Male sex & $0.616(0.351,1.081)$ & 0.091 \\
\hline Body mass index $\left(\mathrm{kg} / \mathrm{m}^{2}\right)$ & $1.074(0.99,1.16)$ & 0.077 \\
\hline Smoking & $1.008(0.49,2.07)$ & 0.98 \\
\hline Diabetes mellitus & $3.153(1.816,5.475)$ & $<0.001$ \\
\hline Hypertension & $0.932(0.52,1.64)$ & 0.808 \\
\hline Previous CVD & $3.339(1.504,7.413)$ & 0.003 \\
\hline HBV & $1.28(0.57,2.84)$ & 0.544 \\
\hline $\mathrm{HCV}$ & $0.77(0.362,1.637)$ & 0.497 \\
\hline Haemodialysis duration (years) & $0.97(0.91,1.02)$ & 0.289 \\
\hline Fistula as blood access & $0.344(0.197,0.601)$ & $<0.001$ \\
\hline Hemodiafiltration & $0.657(0.309,1.397)$ & 0.27 \\
\hline Kt/Vurea (Daugirdes) & $1.054(0.459,2.423)$ & 0.901 \\
\hline nPCR (g/kg/day) & $0.231(0.076,0.703)$ & 0.01 \\
\hline Non-Anuria & $0.487(0.208,1.141)$ & 0.098 \\
\hline Hemoglobin (g/dl) & $0.751(0.611,0.923)$ & 0.006 \\
\hline Serum Albumin (g/dl) & $0.233(0.112,0.483)$ & $<0.001$ \\
\hline WBC $>10^{4}$ & $1.893(0.589,6.078)$ & 0.284 \\
\hline Creatinine (mg/dl) & $0.736(0.649,0.834)$ & $<0.001$ \\
\hline $\mathrm{C}-\mathrm{Ca}$ & $1.055(0.787,1.414)$ & 0.722 \\
\hline Phosphate (mg/dl) & $0.84(0.679,1.040)$ & 0.109 \\
\hline Log ferritin & $1.89(0.96,3.69)$ & 0.062 \\
\hline Log iPTH & $0.685(0.454,1.033)$ & 0.071 \\
\hline Log hsCRP & $2.741(1.593,4.718)$ & $<0.001$ \\
\hline LDL (mg/dl) & $1.007(0.998,1.015)$ & 0.145 \\
\hline Triglyceride (mg/dl) & $1.001(0.999,1.003)$ & 0.268 \\
\hline Pruritus & $2.217(1.257,3.911)$ & 0.006 \\
\hline VAS & $0.85(0.644,1.123)$ & 0.253 \\
\hline Cardiomegaly & $1.763(1.013,3.069)$ & 0.045 \\
\hline
\end{tabular}

Table 3. Multivariate Cox regression analysis of predictors of 24 months cardiovascular mortality. Abbreviations: CVD: cardiovascular disease; hsCRP: high-sensitivity C-reactive protein

\begin{tabular}{lcc}
\hline Variables & $\begin{array}{c}\text { Odds ratio (OR) } \\
\text { 95\% confidence } \\
\text { Intervals (CI) }\end{array}$ & $\mathrm{p}$ \\
\hline Age (years) & $1.053(1.026,1.080)$ & $<0.001$ \\
Diabetes mellitus & $2.957(1.664,5.256)$ & $<0.001$ \\
Previous CVD & $2.845(1.267,6.386)$ & 0.011 \\
Fistula as blood access & $0.538(0.298,0.972)$ & 0.040 \\
Log hs-CRP & $2.241(1.269,3.958)$ & 0.005 \\
Pruritus & $3.164(1.743,5.744)$ & $<0.001$ \\
\hline
\end{tabular}

\section{Discussion}

The pathophysiology of uremic pruritus is not well clarified and multifactorial. The possible mechanisms include immune-hypothesis [14], opioid imbalance [15], histamine and other pruritogens hypothesis [15]. Different treatment modalities and medications such as phototherapy, thalidomide, calcineurin inhibitors, antihistamines and gabapentin have 


\section{Kidney Blood Pressure Research}

Table 4. Univariate and multivariate logistic regression analysis of the predictors of UP in MHD patients. Abbreviations: UP: uremic pruritus; MHD: maintenance haemodialysis; HBV: hepatitis B virus infection; HCV:hepatitis C virus infection; nPCR, normalized protein catabolic rate; iPTH: intact-parathyroid hormone; hsCRP= high-sensitivity C-reactive protein; $\mathrm{LDL}=$ low density lipoprotein; $\mathrm{Kt} / \mathrm{V}_{\text {urea }}=$ dialysis clearance of urea

\begin{tabular}{|c|c|c|c|c|}
\hline Variables & $\begin{array}{l}\text { Univariate logistic regression } \\
\text { Odds ratio (OR) } \\
95 \% \text { confidence Intervals (CI) }\end{array}$ & $P$ & $\begin{array}{l}\text { Multivariate logistic regression } \\
\text { Odds ratio (OR) } \\
95 \% \text { confidence Intervals (CI) }\end{array}$ & $\mathrm{P}$ \\
\hline Body mass index $\left(\mathrm{kg} / \mathrm{m}^{2}\right)$ & $1.07(1.01-1.15)$ & 0.036 & & \\
\hline Diabetes mellitus & $0.46(0.29-0.73)$ & 0.001 & & \\
\hline $\mathrm{HCV}$ & $1.52(1.03-2.23)$ & 0.032 & & \\
\hline Haemodialysis duration (years) & $1.11(1.05-1.15)$ & $<0.001$ & $1.102(1.069,1.137)$ & $<0.001$ \\
\hline Hemodiafiltration & $1.52(1.05-2.20)$ & 0.026 & & \\
\hline Kt/Vurea (Daugirdas) & $2.94(1.8-4.79)$ & $<0.001$ & & \\
\hline nPCR (g/kg/day) & $1.93(1.06-3.51)$ & 0.03 & & \\
\hline Non-Anuria & $0.44(0.27-0.71)$ & 0.001 & & \\
\hline Serum Albumin (g/dl) & $0.57(0.36-0.91)$ & 0.02 & & \\
\hline Log iPTH & $1.52(1.14-2.02)$ & 0.004 & & \\
\hline LDL (mg/dl) & $1.01(1.00-1.01)$ & 0.005 & $1.008(1.002,1.013)$ & 0.006 \\
\hline
\end{tabular}

been tested and used for UP. In this observational study, we found that after adjusted related variables, MHD patient with UP had greater odds for 24-month cardiovascular mortality. However, the severity of UP measured by VAS was not a predictor for cardiovascular mortality.

According to our review of the relevant literatures, studies of UP on mortality in MHD patients were limited. In early period between 1991 to 1995, Balaskas et al. [8] and Carmichael et al. [9] revealed the association between renal itch and mortality. In Balaskas's 24-month observation, the mortality in patients was $24 \%$ with pruritus and $4 \%$ without pruritus, respectively $(\mathrm{p}<0.025)$. After following up 54 MHD patients for 3 years, Carmichael [9] revealed the significant association between high itch VAS and poor outcome. In Narita's study of 1773 MHD patients; severe UP (VAS > 7) was associated with poor outcome in these patients [10]. However, in subgroup analysis, instead of cardiovascular death, infectionrelated mortality was positively associated with itch severity [10]. In our study, Cox regression showed that VAS was not a significant factor to predict 24-month all-cause mortality, cardiovascular-related mortality and infection-related mortality. The severe UP (VAS > 7) was neither a significant predictor for all cause ( $\mathrm{HR}=0.85, \mathrm{p}=0.71)$, cardiovascular-related $(\mathrm{HR}=0.77, \mathrm{p}=0.65)$ and infection-related $(\mathrm{HR}=0.97, \mathrm{p}=0.96)$ mortality. From above cited and our studies, we found that renal itch was associated with higher mortality, but the role of VAS of renal itch on outcome should be further clarified. The different finding with VAS of UP on mortality between above cited and our studies may be due to the VAS was a subjective feeling by patients.

Most of the studies of the impact of UP on mortality were focusing on all-cause mortality $[10,16]$. Our study showed that UP was a significant predictor of cardiovascular mortality in MHD patients. Systemic inflammation in dialysis has been noted to be the major etiology of UP [14]. In our study, after corrected with hsCRP, a surrogate of inflammation, uremic pruritus was still a predictor of cardiovascular mortality in hemodialysis patients. In a retrospective analysis of the DOPPS trial, congestive heart failure had also been noted to be one of the predictor of UP[7]. The DOPPS trial also states the pruritus/mortality relationship may be substantially attributed to poor sleep quality [7]. Mathur et al. showed that sleep disruption due to UP, assessed both by the Itch Medical Outcomes Study (MOS) composite score and the sleep interference question from the Brief Itching Inventory (BII), are significantly associated with the Self-Assessed Disease Severity [17]. Sleep disruption and disturbance have been noted to be associated with CVDs $[18,19]$ and will possible lead to cardiovascular mortality. Congestive heart failure (CHF) had been known to be a factor of cardiovascular mortality in hemodialysis patients [20]. Chronic inflammation has been noted to be a factor associated with CHF in MHD patients [21]. One of the possible mechanism of UP is systemic inflammation in MHD patients. Systemic inflammation, the common mechanism of UP and $\mathrm{CHF}$, might be the reason that UP could predict or correlated with cardiovascular mortality in our study. 


\section{Kidney Blood Pressure Research}

Histamine released by mast cell may also be a contributing factor to UP [16]. Mast cells also had been noted to be associated with eccentric cardiac hypertrophy [22], which had an important impact on mortality in hemodialysis patients [23]. Omae et al. showed that antihistamine therapy had a negative correlation with eccentric cardiac hypertrophy and could improve cardiovascular mortality in hemodialysis patients $[24,25]$. Therefore, the possible correlation between UP and cardiovascular mortality might be due to the release of histamine from mast cell, which could induce both pruritus and eccentric cardiac hypertrophy.

Brain natriuretic peptide (BNP) has been noted to be expressed in a subset of transient receptor potential cation channel subfamily V member 1(TRPV1) neurons, which triggered the itch sensation. BNP knocked out mice lose almost all behavioral responses to itchinducing agents [26]. Shimizu et al. also demonstrated that serum brain BNP associates with the pruritus of hemodialysis patients [27]. Uremic pruritus might be a consequence of elevation of BNP induced by left ventricular pressure and volume overload due to salt and water retention and anemia, and increased blood volume and left ventricular end diastolic dysfunction caused by the arteriovenous vascular access in hemodialysis patients [28-30]. Cardiovascular events and death in hemodialysis patients had been noted to be associated with serum BNP [29].

Our data showed that HD duration was not a predictor of cardiovascular mortality in MHD patients, despite UP patients had longer HD duration. Li et al. showed that high neutrophil/ lymphocyte ratio can predict cardiovascular mortality in chronic hemodialysis patients [31]. The dialysis duration in their study was not correlated with cardiovascular mortality (correlation coefficient $=0.055, \mathrm{P}=0.369$ ). In another study by Losito et al. demonstrated that dialysis duration was one of the predictor of cardiovascular mortality. But the OR was borderline (OR: 1.002, 95\% CI: $1.001-1.004, \mathrm{P}=0.006$ ) [31]. The controversy might be due to not enough duration of follow up and other confounding factors which were correlated with dialysis duration and masked its impact on cardiovascular mortality.

In our present study, Kt/ $\mathrm{V}_{\text {urea }}$ (Daugirdas) was higher in UP patient as compared with patients without UP $(1.89 \pm 0.34$ vs $1.77 \pm 0.32, \mathrm{P}<0.001)$. There were also controversial studies in this subject. Duque et al. showed that higher Kt/V was associated with UP [32]. Ko et al. showed the different result that $\mathrm{Kt} / \mathrm{V} \geq 1.5$ and use of high-flux dialyzer may reduce the intensity of pruritus in patients on chronic hemodialysis [33]. The possible explanation of higher Kt/V in our and Duque's study might be that doctors would increase the dialysis dosage in UP patients trying to reduce the intensity of itch.

Hepatitis $C$ virus infection was significantly more common in patients with UP in this study. Pruritus due to HCV infection has been noted in several studies including HD patients with HCV infection [34-36]. The possible etiologies are HCV- induced cholestasis, increased production of cytokines and chemokines.

The prevalence of infection - related mortality in MHD was not different between patients with and without UP in our study. Narita et al. showed that mortality due to severe UP tended to be more prevalent [10], but the difference was not significant. Skin excoriations from scratching can lead to skin infections. Approximate $9 \%$ of infection episodes of longterm dialysis patients were skin and soft tissue infections [37]. The definite association between UP, skin infections, other infection sources and infection related mortality needed further investigations.

\section{Conclusion}

Uremic pruritus was one of the predictor of 24-month cardiovascular mortality in MHD patients. Nephrologists should be mindful of cardiovascular risks in hemodialysis patients, especially those with UP. 


\section{Kidney Blood Pressure Research}

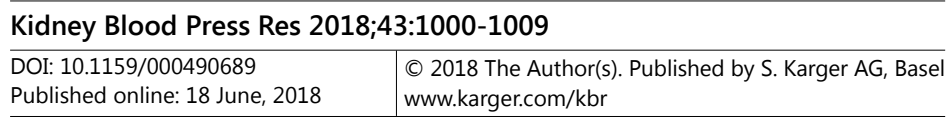

Weng et al.: Uremic Pruritus and Cardiovascular Mortality

\section{Acknowledgements}

Cheng-Hao Weng is funded by research grant from the Chang Gung Memorial Hospital, Taiwan (CMRPG5G0031). And Wen-Hung Huang is funded by research grants from the Chang Gung Memorial Hospital, Taiwan (CMRPG3G0511).

\section{Disclosure Statement}

The authors declare no conflicts of financial interest.

\section{References}

1 Aucella F, Gesuete A: [Uremic pruritus: an unresolved challenge]. G Ital Nefrol 2009;26:585-599.

$\rightarrow 2$ Chiu YL, Chen HY, Chuang YF, Hsu SP, Lai CF, Pai MF, Yang SY, Peng YS: Association of uraemic pruritus with inflammation and hepatitis infection in haemodialysis patients. Nephrol Dial Transplant 2008;23:36853689.

3 Marquez D, Ramonda C, Lauxmann JE, Romero CA, Vukelic VL, Martinatto C, Barron B, Novoa PA, Peixoto AJ, Orias M: Uremic pruritus in hemodialysis patients: treatment with desloratidine versus gabapentin. J Bras Nefrol 2012;34:148-152.

4 Murphy M, Reaich D, Pai P, Finn P, Carmichael AJ: A randomized, placebo-controlled, double-blind trial of ondansetron in renal itch. Br J Dermatol 2003;148:314-317.

5 Pauli-Magnus C, Mikus G, Alscher DM, Kirschner T, Nagel W, Gugeler N, Risler T, Berger ED, Kuhlmann U, Mettang T: Naltrexone does not relieve uremic pruritus: results of a randomized, double-blind, placebocontrolled crossover study. J Am Soc Nephrol 2000;11:514-519.

6 Kimata N, Fuller DS, Saito A, Akizawa T, Fukuhara S, Pisoni RL, Robinson BM, Akiba T: Pruritus in hemodialysis patients: Results from the Japanese Dialysis Outcomes and Practice Patterns Study (JDOPPS). Hemodial Int 2014;18:657-667.

7 Pisoni RL, Wikstrom B, Elder SJ, Akizawa T, Asano Y, Keen ML, Saran R, Mendelssohn DC, Young EW, Port FK: Pruritus in haemodialysis patients: International results from the Dialysis Outcomes and Practice Patterns Study (DOPPS). Nephrol Dial Transplant 2006;21:3495-3505.

8 Balaskas EV, Grapsa E: Uremic pruritus is a poor prognostic factor of outcome. Perit Dial Int 1995;15:177.

9 Carmichael AJ, McHugh MI, Martin AM: Renal itch as an indicator of poor outcome. Lancet 1991;337:12251226.

-10 Narita I, Alchi B, Omori K, Sato F, Ajiro J, Saga D, Kondo D, Skatsume M, Maruyama S, Kazama JJ, Akazawa K, Gejyo F: Etiology and prognostic significance of severe uremic pruritus in chronic hemodialysis patients. Kidney Int 2006;69:1626-1632.

11 Mailloux LU, Bellucci AG, Wilkes BM, Napolitano B, Mossey RT, Lesser M, Bluestone PA: Mortality in dialysis patients: analysis of the causes of death. Am J Kidney Dis 1991;18:326-335.

$\checkmark 12$ Fallahzadeh MK, Roozbeh J, Geramizadeh B, Namazi MR: Interleukin-2 serum levels are elevated in patients with uremic pruritus: a novel finding with practical implications. Nephrol Dial Transplant 2011;26:33383344 .

-13 Chirakarnjanakorn S, Navaneethan SD, Francis GS, Tang WH: Cardiovascular impact in patients undergoing maintenance hemodialysis: Clinical management considerations. Int J Cardiol 2017;232:12-23.

14 Kimmel M, Alscher DM, Dunst R, Braun N, Machleidt C, Kiefer T, Stulten C, van der Kuip H, Pauli-Magnus C, Raub U, Kuhlmann U, Mettang T: The role of micro-inflammation in the pathogenesis of uraemic pruritus in haemodialysis patients. Nephrol Dial Transplant 2006;21:749-755.

15 Yosipovitch G, Greaves MW, Schmelz M: Itch. Lancet 2003;361:690-694.

16 Mettang T, Kremer AE: Uremic pruritus. Kidney Int 2015;87:685-691.

17 Mathur VS, Lindberg J, Germain M, Block G, Tumlin J, Smith M, Grewal M, McGuire D, Investigators INR: A longitudinal study of uremic pruritus in hemodialysis patients. Clin J Am Soc Nephrol 2010;5:1410-1419. 


\section{Kidney \\ Blood Pressure Research}

18 Phillips B, Mannino DM: Do insomnia complaints cause hypertension or cardiovascular disease? J Clin Sleep Med 2007;3:489-494.

19 Meisinger C, Heier M, Lowel H, Schneider A, Doring A: Sleep duration and sleep complaints and risk of myocardial infarction in middle-aged men and women from the general population: the MONICA/KORA Augsburg cohort study. Sleep 2007;30:1121-1127.

20 McCullough PA, Chan CT, Weinhandl ED, Burkart JM, Bakris GL: Intensive Hemodialysis, Left Ventricular Hypertrophy, and Cardiovascular Disease. Am J Kidney Dis 2016;68:S5-S14.

-21 Libetta C, Sepe V, Zucchi M, Pisacco P, Cosmai L, Meloni F, Campana C, Rampino T, Monti C, Tavazzi L, Dal Canton A: Intermittent haemodiafiltration in refractory congestive heart failure: BNP and balance of inflammatory cytokines. Nephrol Dial Transplant 2007;22:2013-2019.

-22 Janicki JS, Brower GL, Gardner JD, Forman MF, Stewart JA, Jr., Murray DB, Chancey AL: Cardiac mast cell regulation of matrix metalloproteinase-related ventricular remodeling in chronic pressure or volume overload. Cardiovasc Res 2006;69:657-665.

-23 Stack AG, Saran R: Clinical correlates and mortality impact of left ventricular hypertrophy among new ESRD patients in the United States. Am J Kidney Dis 2002;40:1202-1210.

24 Omae K, Ogawa T, Yoshikawa M, Nitta K: The use of H1-receptor antagonists and left ventricular remodeling in patients on chronic hemodialysis. Heart Vessels 2010;25:163-169.

25 Omae K, Yoshikawa M, Sakura H, Nitta K, Ogawa T: Efficacy of antihistamines on mortality in patients receiving maintenance hemodialysis: an observational study using propensity score matching. Heart Vessels 2017;32:1195-1201.

26 Mishra SK, Hoon MA: The cells and circuitry for itch responses in mice. Science 2013;340:968-971.

27 Shimizu Y, Sonoda A, Nogi C, Ogushi Y, Kanda R, Yamaguchi S, Nohara N, Aoki T, Yamada K, Nakata J, Io H, Kurusu A, Hamada C, Horikoshi S, Tomino Y: B-type (brain) natriuretic peptide and pruritus in hemodialysis patients. Int J Nephrol Renovasc Dis 2014;7:329-335.

-28 Amerling R, Ronco C, Kuhlman M, Winchester JF: Arteriovenous fistula toxicity. Blood Purif 2011;31:113120.

29 Foley RN, Curtis BM, Randell EW, Parfrey PS: Left ventricular hypertrophy in new hemodialysis patients without symptomatic cardiac disease. Clin J Am Soc Nephrol 2010;5:805-813.

-30 Iwashima Y, Horio T, Takami Y, Inenaga T, Nishikimi T, Takishita S, Kawano Y: Effects of the creation of arteriovenous fistula for hemodialysis on cardiac function and natriuretic peptide levels in CRF. Am J Kidney Dis 2002;40:974-982.

-31 Li H, Lu X, Xiong R, Wang S: High Neutrophil-to-Lymphocyte Ratio Predicts Cardiovascular Mortality in Chronic Hemodialysis Patients. Mediators Inflamm 2017;2017:9327136.

32 Duque MI, Thevarajah S, Chan YH, Tuttle AB, Freedman BI, Yosipovitch G: Uremic pruritus is associated with higher kt/V and serum calcium concentration. Clin Nephrol 2006;66:184-191.

-33 Ko MJ, Wu HY, Chen HY, Chiu YL, Hsu SP, Pai MF, Ju Y, Lai CF, Lu HM, Huang SC, Yang SY, Wen SY, Chiu HC, Hu FC, Peng YS, Jee SH: Uremic pruritus, dialysis adequacy, and metabolic profiles in hemodialysis patients: a prospective 5-year cohort study. PLoS One 2013;8:e71404.

34 Lebovics E, Seif F, Kim D, Elhosseiny A, Dworkin BM, Casellas A, Clark S, Rosenthal WS: Pruritus in chronic hepatitis C: association with high serum bile acids, advanced pathology, and bile duct abnormalities. Dig Dis Sci 1997;42:1094-1099.

-35 Alhmada Y, Selimovic D, Murad F, Hassan SL, Haikel Y, Megahed M, Hannig M, Hassan M: Hepatitis C virusassociated pruritus: Etiopathogenesis and therapeutic strategies. World J Gastroenterol 2017;23:743-750.

-36 Goodkin DA, Bieber B, Jadoul M, Martin P, Kanda E, Pisoni RL: Mortality, Hospitalization, and Quality of Life among Patients with Hepatitis C Infection on Hemodialysis. Clin J Am Soc Nephrol 2017;12:287-297.

-37 Berman SJ, Johnson EW, Nakatsu C, Alkan M, Chen R, LeDuc J: Burden of infection in patients with endstage renal disease requiring long-term dialysis. Clin Infect Dis 2004;39:1747-1753. 